\title{
SVECI ZAŠTITNICI U POBOŽNOSTI KRIVOPUĆANA
}

\author{
Marijana BELAJ \\ Filozofski fakultet Sveučilišta u Zagrebu \\ Odsjek za etnologiju i kulturnu antropologiju \\ Ivana Lučića 3, 10000 Zagreb
}

\section{UVOD'}

$\mathrm{P}$ rema nauku Katoličke crkve svetačka je uloga u životu vjernika u prvome redu biti modelom uzoritosti i nasljedovanja (Hoško 2001a:379). No, još od kasnoga srednjeg vijeka puk svecima pridaje i ulogu zaštitnika u raznovrsnim životnim prigodama - sveci se u tom razdoblju specijaliziraju u zaštitnike u pojedinim nevoljama (ibid.:373). Pojedine kršćanske svece puk smatra zaštitnicima od bolesti, zaštitnicima stoke, zaštitnicima biljnog uzgoja, protiv vremenskih nepogoda i drugih šteta, zaštitnicima nekih djelatnosti i zanimanja te zaštitnicima ljudi tj. dobnih i spolnih skupina, životnih ciklusa te osobina i statusa (Belaj, M. 2006:31). Na svetačku specijalizaciju ponajviše su utjecale legende o svecima jer rijetko postoje povijesne opravdanosti za neku svetačku zaštitničku ulogu. K tome, novokršteni su narodi u kult svetaca unijeli sebi svojstvene nekršćanske predaje, vjerovanja i obrede čiji su tragovi ostali očuvani i do danas (Hoško 2001a:374). Time se štovanje svetaca kao zaštitnika pokazuje izrazom pučke pobožnosti, a u okviru njega iščitava se osobit odnos prema nadnaravnom i predodžbe o uređenju svijeta te mjestu čovjeka u njemu.

Vjerovanje u svece kojima Krivopućani dodjeljuju zaštitničke uloge u ovome se prilogu sagledava s etnološkoga/kulturnoantropološkoga stajališta, tj. kao kulturna pojava. Prosuđivanje vjerskoga aspekta, svojstveno teološkom pristupu, ovdje nije relevantno. U skladu s time, promatra se jedan aspekt pučke pobožnosti - pobožnosti koja nije opterećena naukom Crkve niti je Crkvom upravljana, no vjerske predodžbe, o kojima će ovdje biti riječi, sa stajališta puka doživljavaju se dijelom službenoga (istoga) religijskog okvira i smatraju se istinitima. Stoga ih ne treba gledati u sukobu s kršćanskim naukom - radi se o istoj religiji koja se kroz religioznost živi i prakticira i drukčije od propisanoga, ali u prožimanju s njime (Belaj, M. 2006:9-11). ${ }^{2}$ Vjerovanja, postupci i stavovi koji tvore pučku pobožnost uokvireni su određenim povijesnim, kulturnim i društvenim okvirom te su često sačuvani kroz dulje razdoblje. Slijedom toga i štovanje svetaca, dulija ${ }^{3}$, nosi kulturološka obilježja prostora u kojemu se javlja te pokazuje procese rasta i opadanja u određenim vremenskim razdobljima. Pučko štovanje svetaca zaštitnika iskazuje se brojnim i raznovrsnim oblicima (usp. ibid.:12), a u vjerničkoj praksi mnogi se od tih oblika pobožnosti međusobno isprepliću.

Štovanje svetaca zaštitnika (izvan liturgije i crkvenog vodstva) uraslo je u život Krivopućana, što ću nastojati prikazati ovim prilogom ponajprije kroz oblike štovanja svetaca zaštitnika na ovomu području, te značenje koje tim svecima mještani pridaju.

Djelomice izmijenjena i dopunjena inačica ovoga rada objavljena je u Studia ethnologica Croatica, vol. 19:47-76 (2007).

2 O tome da odnos između pučkog i službenog nije rivalski, već recipročan, te da se radi o kruženju ideja između dvoga, govore mnogi autori (primjerice, Belaj, V. 1988:191; Eliade 1970:153-156; O'Connor 1999:384-385; Rihtman-Auguštin 1991:10; Zečević 2000:72-74), pa i teolozi (primjerice, Bezić 1981:314-315), kao i uostalom, povijesni razvoj pučke pobožnosti i službene (kršćanske) Crkve uopće (primjerice, usp. Hoško 2001b:384-392).

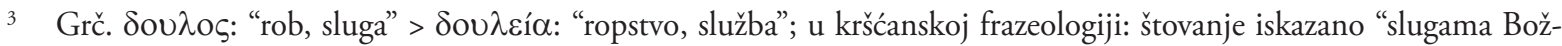
jim", tj. svecima. U katolicizmu i pravoslavlju razlikuje se kult koji se iskazuje Bogu (latrija), kult koji se iskazuje Bogorodici (hiperdulija) te kult koji se iskazuje svecima i anđelima (dulija) (Rebić, ur. 2002:105-106,492). 
Istraživanje prisutnosti svetaca u krivoputskoj zajednici provela sam kroz kontekst godišnjih običaja jer on ukazuje na složeno i raznoliko značenje svetaca i na raznolikost pobožnih izraza kojima se to značenje iskazuje. Osim toga, prizma godišnjih običaja pruža dobru sliku o stvarnoj prisutnosti pojedinih svetaca zaštitnika u pobožnosti te o njihovim međusobnim odnosima i važnosti koje im zajednica pridaje u svom u životu. Važno je naglasiti da iako prizma godišnjih običaja nužno stavlja naglasak na spomendane svetaca, a ne na njihovu zaštitničku ulogu, ona pruža bolji uvid u izvaninstitucionalne postupke i prateća vjerovanja. Tu, naime, do izražaja posebice dolaze pučki blagoslovi, procesije, proricanja, zabrane postupaka i dr. U istraživanju svetaca zaštitnika u pobožnosti krivoputske zajednice krenula sam, dakle, od spomendana svetaca koje puk obilježava izvan dometa službene Crkve.

Tijekom istraživanja zanimalo me u kojim se prigodama vjerovanje u svece javlja i kako se ono izražava. Prateći slijed spomendana, kako su ih isticali moji sugovornici, usredotočila sam se na sadržaj postupaka koji se izvode i njihova značenja za one koji ih izvode, a osobito u vezi sa svecem na čiji se dan postupak odvija. Potom su me zanimale i eventualne promjene u postupcima tijekom vremena i način na koji se to odražava u vezi s vjerovanjem u zaštitničku ulogu sveca. Naposlijetku me zanimalo što mogu istraženi postupci i vjerovanja reći o pobožnosti ispitane zajednice kao i o zajednici uopće.

\section{GRADIVO: SVECI ZAŠTITNICI I OBLICI ŠTOVANJA}

$\mathrm{I}^{\mathrm{s}}$ straživanje, čije ću rezultate prikazati, provela sam 2004. godine u sljedećim selima i zaseocima na području Krivoga Puta: Krivi Put, Podbilo, Šojatski Dolac, Pavići, Prpići, Lucići i Veljun. ${ }^{4}$ Važno je napomenuti da najveću popularnost među svecima zaštitnicima na području Krivoga Puta ima Majka Božja Snježna kojoj je posvećena krivoputska crkva, smještena u zaselku Podbilo i podignuta 1856. godine. Osim toga, katkad se u pobožnosti spominje i Majka Božja Krasnarska - prema nekim kazivanjima, drugi lik Majke Božje.

Iako se u svom radu ne bavim pobožnostima prema Majci Božjoj (kao što sam već navela, u radu je riječ o duliji), nužno je ukratko osvrnuti se i na bitne značajke štovanja ove svetice radi stjecanja cjelovitije slike o krivoputskoj pobožnosti. ${ }^{5}$

Kao što sam to zamijetila i u nekim drugim zajednicama (usp. ibid.:213-218), govor Krivopućana o svom vjerovanju u svece zaštitnike gotovo redovito polazi od titulara lokalne i mjesnih crkava. Krivopućani u tom govoru redovito navode sljedeće titulare: krivoputsku Majku Božju Snježnu, senjskoga sv. Jurja, Majku Božju u Krasnu te sv. Mihovila na Vratniku. Majku Božju Snježnu nazivaju našom Snježnom Gospom, zaštitnicom našeg mjesta, našom sveticom, našom zaštitnicom ili lokalnom zaštitnicom dok ostale nazivaju njihov zaštitnik. „Svojatanje“ svetice razvidno je i u predaji o izgradnji crkve. Predaja donekle odgovara onoj o crkvi Santa Maria Maggiore u Rimu, s tim da su lokacije koje se spominju u domaćoj varijanti smještene u područje Podbila (Kulišić i Vuković 2004:244-255). Nadalje, kad je riječ o lokalnim titularima, posebice Majci Božjoj Snježnoj, Krivopućani se često pozivaju na obilježavanje blagdana, tj. na tzv. zbor te time ukazuju na važnost Majke Božje Snježne u društvenosti krivoputske zajednice. Štoviše, većina Krivopućana vidi važnost njezina blagdana upravo u druženju i zabavi. O tome slikovito govori i podatak da neki kazivači i za taj aspekt događanja rabe pojam zavit (inače se najčešće rabi u značenju ispunjenja obveze prema svecu, primjerice hodočašća). Primjerice:

4 Gradivo sam prikupila u suradnji s apsolventicom etnologije Ivanom Vuković. Radi očuvanja diskrecije mojih sugovornika, koje je nužno pri objavi gradiva u okviru ovakve teme, umjesto njihovih imena navodit ću lokalitete u kojima prebivaju kao reference za prikupljene podatke.

5 Radi iscrpnijeg uvida u štovanje ove svetice upućujem na prilog M. Kulišić i I. Vuković u ovoj monografiji. Pobožnost Majci Božjoj Snježnoj istraživala sam i u sklopu vjerovanja u svece zaštitnike. Spomenute su apsolventice ta istraživanja upotpunile praćenjem zbivanja oko proslave blagdana Majke Božje Snježne 2004. godine. Oba istraživanja objavile su u cjelini (Kulišić i Vuković 2004), a taj se prilog, dijelom nadopunjen, nalazi i u ovoj monografiji. 
[Jeste li vi išli na zavit?] A da što sam, nego. Bio sam ja prvi put kad sam imao 17 godina, 47. A nije baš bilo zbog bolesti. Bija sam mlad, društvo, cure, dečki, i skupili se i idemo (Šojatski Dolac).

U vezi s okupljanjem zajednice, ali i s njezinom identifikacijom je i činjenica da na ovaj blagdan dolaze i raseljeni Krivopućani. Iseljeno stanovništvo, kako ističu kazivači, ne dolaze u Krivi Put ni za Božić, ni za Uskrs, već upravo na blagdan ove svetice (ibid.:253).

Majka Božja Snježna pokazuje se bitnim činiteljem u oblikovanju identiteta zajednice, a njezin je spomendan važna okosnica društvenog života, ne samo stalnih stanovnika, već i onih iseljenih. Proslava blagdana Majke Božje Snježne pokazuje se središnjim godišnjim događajem u životu Krivopućana. No, kad je riječ o svecima odabranima za zaštitnike i tu je Majka Božja Snježna snažno prisutna (usp. ibid.:245-248, 255-257; Kulišić i Vuković u ovoj monografiji; Belaj, M. 2006:236-237), isključivo kao svetica koju vjernik odabire za svoju osobnu zaštitnicu. Njezina dominatna uloga u iskazima kazivača o osobnim svecima zaštitnicima govori kako je ona svojom pojavom i značenjem duboko integrirana $u$ zajednicu. Time Majka Božja ujedno utječe na slabu popularnost ostalih svetaca kao osobnih zaštitnika. Štoviše, osim nekoliko naznaka osobne pobožnosti prema sv. Antunu Padovanskom, uočenih tijekom proslave blagdana Majke Božje Snježne (Kulišić i Vuković 2004:255) i uopće u kazivanjima (v. niže), nema potvrda o drugim svecima odabranima za osobnoga zaštitnika. No, njihova je uloga u pobožnosti Krivopućana uglavnom usmjerena na gospodarski boljitak. Upravo je prizma godišnjih običaja ukazala na štovanje drugih svetaca zaštitnika, kao i na brojnost uloga i prigoda u kojima se ono javlja te raznovrsnost oblika putem kojih se izražava.

Sveci koji su kao zaštitnici prisutni u životu gotovo svih Krivopućana jesu: sv. Josip, sv. Juraj, sv. Marko, sv. Antun Padovanski, sv. Ilija i sv. Lucija. Osim njih, prisutni su i neki drugi, no ne kao zaštitnici, već samo u vidu svojih spomendana koji su za Krivopućane ključni dani u godišnjem ciklusu.

U prikazu pobožnosti prema krivoputskim svecima zaštitnicima slijedit ću tijek godine. Nakon njih prikazat ću i ključne dane u godišnjem ciklusu.

\subsection{SV. JOSIP}

Cvetoga Josipa na području Krivoga Puta povezuju sa šumom - nazivaju ga šumski svetac ${ }^{6}$ ili mu u vjero-

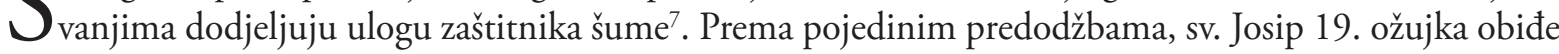
svako stablo u šumi i o njega udara čekićem unoseći tako u njega vegetaciju (mezgru). ${ }^{8}$ Stoga, pucketanje stabala koje se čuje u to doba godine neki $i^{9}$ povezuju s Josipovim udaranjem čekićem o njih. U vezi s ovim vjerovanjem postoje i izreke: Sv. Josip drvo kuca, od drveta kora puca ${ }^{10}$ ili Sv. Josip kuc, drvo puc. ${ }^{11}$

Nadalje, s ovim su vjerovanjem povezane i neke zabrane. Na spomendan sv. Josipa (19. ožujka), nije se odlazilo u šumu jer se to smatralo opasnim. ${ }^{12}$ Vjerovalo se, naime, da bi taj dan na čovjeka u šumi mogla pasti kakva grana i ozlijediti ga. ${ }^{13}$ Vjerovanje je potkrijepljeno i pričom o čovjeku koji nije na ovaj način poštivao spomendan sv. Josipa pa je na njega pala suha bukova grana (bilja) i ubila ga. ${ }^{14}$ Ovu su zabranu, prema jednom kazivanju, stariji ljudi proširivali i na rad oko drveta uopće. ${ }^{15}$ Prema nekim drugim kazivanjima, samo šumari nisu radili u šumi na Josipovo. ${ }^{16}$

\footnotetext{
Veljun, Prpići, Podbilo.

Veljun, Pavići.

Veljun, Pavići, Prpići.

Veljun, Prpići.

Prpići.

1 Podbilo.

2 Veljun, Pavići, Podbilo.

3 Veljun, Pavići.

14 Pavići.

15 Veljun.

16 Veljun, Prpići.
} 
I danas se, prema nekima, poštuje zabrana odlaska u šumu - vjeruju da je tako dobro, jer tako su vjerovali stari. ${ }^{17}$ Drugi pak navode da na Josipovo odlaze u šumu i vjeruju da nema nikakve opasnosti, ali poštuju ovaj dan pa ne smiju raditi u njoj. ${ }^{18}$

Josipovo je također bio dan s kojim prestaje sječa stabala, a ona se nastavila nakon Miholja, tj. nakon otpadanja lišća. ${ }^{19}$ Neki kazivači ističu da danas više nitko za to ne mari, pa se stabla sjeku upravo u tom razdoblju jer što je zelenije to je ljepše. ${ }^{20}$

\subsection{SV. JURAJ}

Sveti Juraj je u vjerovanjima Veljunara zaštitnik polja te je prije 60-ak godina bilo rašireno vjerovanje da donosi plodnost zemlji. Osim toga u Prpićima se navodi da je zaštitnik konja, a u Veljunu i Lucićima da je općenito zaštitnik stoke. Kazivačima u Krivome Putu i u Šojatskome Dolcu nije poznata stočarska uloga sv. Jurja, no njegov dan obilježavaju u vezi sa stokom, kako ćemo kasnije vidjeti. Jedna pak kazivačica iz Podbila navodi obilježavanje spomendana sv. Jurja u vezi s postupcima sa stokom, ali vjeruje da je zaštitnik stoke sv. Antun Padovanski.

Na spomendan sv. Jurja (23. travnja) u crkvi Majke Božje Snježne u Krivom Putu nema posebne mise. Ipak, među stanovništvom sela i zaselaka na području Krivoga Puta spomendan sv. Jurja raznoliko se obilježava, uglavnom u skladu s gore navedenim vjerovanjima vezanim uz toga sveca. U tom raznolikom obilježavanju ipak postoje neke pravilnosti. Primjerice, jedan Veljunar ovaj spomendan naziva domašnjakom, odnosno spomendanom koji se obilježava zabranom rada samo do mise na taj dan, dok je nakon mise dozvoljeno sve raditi. Druga Veljunarka navodi pak da se uopće nije radilo, a tko je bio voljan odlazio bi u crkvu u Sv. Juraj. No, najrašireniji čin kojim se obilježava ovaj dan je blagoslov stoke ${ }^{21}$ koja, kako Veljunari navode, tada prvi puta izlazi iz staje.

Stoka se blagoslivlja blagoslovljenom vodom i grančicom. Voda koja se za to koristi blagoslovljena je ili na Cvjetnicu ili oko Nove godine ili bilo kada - kazivači govore da to nije važno. U Veljunu neki navode da se voda nije koristila pri blagoslivljanju ${ }^{22}$. Grančica je blagoslovljena na Cvjetnicu i gotovo uvijek se radi o drijenovini² ${ }^{23}$, osim što jedna Veljunarka spominje maslinovu grančicu, a kazivači iz Krivoga Puta govore da se ona jednostavno taj čas otkine (pa nije blagoslovljena). Postupak blagoslova bio je vrlo jednostavan: grančicom se sva stoka lagano udari (izrene), a vodom se poškropi staja. Milan Prpić Markin iz Veljuna istaknuo je da se pritom izgovara: Blagoslovija te Bog svemogući, stvoritelj neba i zemlje i očuva narod, stoku i zemlju od nećastivih i nereda, tuče, grada... Ostali kazivači tvrde da se pritom ništa posebno nije izgovaralo, već se stoka samo potjerala van. Prema jednom kazivanju iz Podbila ovaj su blagoslov radile isključivo gazdarice.

Malo drukčiji blagoslov spominje jedan kazivač iz Šojatskoga Dolca te neki Veljunari. Oni, naime, navode kako se stoka blagoslivljala rasolom (koji se čuvao u boci) koji bi odstajao od zime, kada se kuhalo svinjsko meso u kiselom kupusu. Kazivač iz Šojatskoga Dolca navodi da se to kuhalo oko Božića ili ranije, dok spomenuti Veljunari navode vrijeme oko Poklada. Također, između ovih kazivača postoje manja odstupanja u opisu kako se to radilo. Kazivač iz Šojatskoga Dolca ističe kako je gazdarica škropila tim rasolom, obilazeći kuću i staju, a Veljunari govore da su gazdarice rasolom mazale njuške stoci. Postupak se provodio, kako svi ovi kazivači spominju, radi zaštite od ugriza zmije ili pak da nešto nepoželjno ne ulazi u staju i podrum (Šojatski Dolac) ili da ne bi stradala vimena (Veljun). Istodobno bi se, kako svi navode, uz

\footnotetext{
Veljun.

Veljun, Podbilo.

Veljun, Pavići, Prpići, Podbilo.

Veljun, Prpići.

Podbilo, Šojatski Dolac, Krivi Put, Veljun.

Veljun.

Veljun, Podbilo.
} 
to nosila zažarena maslinova grančica da malo dimi. Grančica je morala biti blagoslovljena na Cvjetnicu. Prema kazivaču iz Šojatskoga Dolca njome bi se pomazalo i blago po njušci da ga ne ugrize zmija, a pritom se križalo i govorilo Otac i Sin i Duh Sveti. Njegova je supruga, uz maslinovu grančicu palila i češnjak da se bolje dimi. Kazivači iz Veljuna nisu željeli reći što se pri ovom postupku govorilo.

U Veljunu se spominje i da je gazdarica taj dan na svakom govedu pri izlasku iz staje s blagoslovljenom šibom napravila znak križa. Šiba, drijenova ili maslinova, morala je biti blagoslovljena na Cvjetnicu. Potom je pastir, koji je vodio stoku na ispašu, uzeo od gazdarice tu šibu i nije ju smio izgubiti, već ju je morao vratiti. Šiba se mogla i slomiti, ali je morao donijeti makar njen komadić. Vjerovalo se da ako pastir ne donese šibu natrag, blago će se gubiti kroz cijelu godinu. Ako je pastir donese, vjerovalo se da će blago i bez njega znati doći kući. Šiba se poslije stavila na gredu u staji, iznad blaga.

Maslinove grančice, blagoslovljene na Cvjetnicu i zataknute za gredu u staji, spominju i kazivači iz Krivoga Puta, no nevezano uz blagoslov na Jurjevo. Prema njihovu kazivanju, njezina je namjena unošenje malo blagoslova u staju i čuvanje staje i stoke od zla. Takve sam grančice vidjela i u nekim stajama na području Mrzloga Dola.

Mnogi od ovih kazivača koji su govorili o blagoslovu stoke na Jurjevo više to ne rade iz jednostavnog razloga, kako su naveli, jer više nemaju krave, volove, magarce i dr. Također, ne znaju zašto se to radilo baš na Jurjevo, no ističu kako je to staro ili oduvijek, ne bi li naglasili duboku starinu ovoga postupka i njegovo trajanje kroz vrijeme koje nadilazi njihova sjećanja.

Stoci se od Jurjeva zabranjuje ići na pašu širom po livadama, kako bi se sačuvalo livade za kosidbu. Nakon kosidbe stoka ponovno može slobodno pasti po livadama. ${ }^{24}$

Na Jurjevo je u ovome kraju također vrlo raširena zabrana oranja vlastite zemlje s vlastitom stokom, no vlastita se stoka može ponuditi susjedu za oranje ${ }^{25}$. Kao razlozi poštivanja ove zabrane navodi se da se tako radi, jer su tako radili i njihovi stari ${ }^{26}$ ili da je to za sreću blaga ${ }^{27}$. Marija i Ivan Prpić Kavarica iz Lucića spominju da su se na Jurjevo raskivali konji da ne vrijeđaju zemlju.

Uz spomendan sv. Jurja često se na ispitivanom području spominjalo proricanje o budućem vremenu. Govori se i vjeruje da ako je sv. Juraj došao na zelenom konju da slijedi dobra godina, a ako dođe na crnom konju godina će biti nerodna i loša. ${ }^{28}$ Kao što su neki kazivači objasnili, radi se o tome da na Jurjevo gledaju je li šuma (gora) prozelenila ili nije. ${ }^{29}$

Iako većina kazivača govori da se oko Jurjeva nisu palile vatre, neki ih Veljunari spominju. Jedna od njih navela je da joj je baba pričala kako su se navečer uoči Jurjeva vatre palile oko kuće, ispred štale i na križanjima putova. Dvoje je Veljunara navelo, pak, da je na početku toga dana cijelo selo na jednome mjestu palilo vatru. $U$ tome su sudjelovali uglavnom mladi iz sela, koji su vatru i preskakivali. No, to se nije radilo, kako su naveli, ni zbog čega drugog, nego iz zabave.

\subsection{SV. MARKO}

Sveti je Marko u vjerovanju, kao i sv. Juraj, zaštitnik polja koji donosi plodnost zemlji. ${ }^{30} \mathrm{Njega}$ se i zazivalo poput: Sv. Marko, daj rod. ${ }^{31}$ Molilo ga se da padne kiša ${ }^{32}$, a i da pobije crve i miševe u zemlji. ${ }^{33}$

4 Podbilo, Krivi Put, Pavići, Prpićí, Lucići, Veljun.

5 Krivi Put, Podbilo, Šojatski Dolac,Veljun, Pavići, Lucići.

6 Šojatski Dolac, Pavići.

7 Krivi Put, Podbilo, Veljun.

28 Krivi Put, Podbilo, Pavići, Prpići, Veljun.

29 Krivi Put, Podbilo, Veljun.

30 Veljun, Podbilo.

31 Veljun.

32 Veljun.

33 Podbilo, Veljun. 
Kiša na Markovo (25. travnja) doživljavala se pravim blagoslovom. ${ }^{34}$ Jedna je Veljunarka spomenula i nekadašnje procesije oko crkve na Markovo, koje su se održavale za kišu, ako je razdoblje prije Markova sušno. Neki drugi kazivači iz Veljuna naveli su da se na Markovo blagoslivljalo polja, bilo sa svećenikom, bilo bez njega. ${ }^{35}$ Nastojalo se i ne lijegati na travu dok ne prođe spomendan ovoga sveca. ${ }^{36}$

\subsection{SV. ANTUN PADOVANSKI}

Svetome je Antunu Padovanskom u vjerovanju na ovome području najčešće dodijeljena uloga zaštitnika $S_{\text {stoke. }}{ }^{37}$ Mnogi su kazivači istaknuli da vjerovanje u sv. Antuna kao zaštitnika stoke postoji od starine ili oduvijek. ${ }^{38}$ Sv. Antuna Padovanskog svakodnevno se molilo da čuva stoku na ispaši ${ }^{39}$, a osobito kad je stoka bolesna ili kad se teli krava ${ }^{40}$. Osim molitve Očenašst , pritom se su mogli izgovarali jednostavni zazivi poput: Sv. Ante, očuvaj blago ${ }^{42}$ ili Sv. Ante, pomozi da se riješi ${ }^{43}$ kad bi se trebala krava oteliti. Kazivačica, sedamdesetogodišnjakinja, iz Podbila sjeća se da je u njezinoj obitelji svakoj večeri obavezno prethodila molitva sv. Antunu Padovanskom da odškapula blago od zmije, vuka, ujidi, tata, škrape..., a osobito se molilo kad se nešto stoci dogodilo, primjerice, od ujida, nakon što je zmija ugrizla kravu. Kazivačica se, nažalost ne sjeća majčine molitve, no sjeća se njezine svakodnevne važnosti: (...) večera - nema, čekaš ko zeban sunca da će ti dat ono pojest, ali mora se ić prije molit. I onda je ona [majka] to sazivala. Ja ni ne znam. Vjerovanje u sv. Antuna Padovanskog kao zaštitnika stoke i sama je preuzela, moleći ga da spasi blago od svakoga zla i izgovarajući pritom molitve Očenaš ili Zdravomarijo.

Osim što je, prema vjerovanjima, sv. Antun zaštitnik sve stoke, jedna Veljunarka, uz navedeno, još posebno naglašava njegovu ulogu čuvara ovaca, kojega su nastojali umilostiviti tako što bi prigodom šišanja ovaca na vrhu glave i repa ostavili par pramenova runa sv. Anti za šlape.

Samo su dvoje Veljunara spomenuli da se sv. Antunu Padovanskom na njegov blagdan plaćala misa kako bi očuvao stoku od zla.

Danas se sv. Antunu Padovanskom manje moli za pomoć oko stoke, jer, kako je to primjerice objasnila jedna Podbilarka, malo tko ima stoku. No, sv. Antun Padovanski, kao pomoćnik u raznim nevoljama, prisutan je i na ovome području. Spomenuta kazivačica navodi da mu se molila i kad je rađala: Sv. Ante budi mi u pomoći ili: $O$ sv. Ante, odškapulaj me od svakog zla $i$ da mi se on živ i zdrav rodi. Nije sigurna je li joj to $s v$. Ante dao, no istakla je kako je rodila četvero djece kod kuće i porodi su prošli brzo i bez posljedica.

Općepoznata uloga sv. Antuna kao pomoćnika u pronalaženju izgubljenih stvari spomenuta je samo u anegdoti koju je ispričao jedan kazivač iz Krivoga Puta. Naime, neki je čovjek izgubio novčanik (briktaš), pa mu je jedna baba rekla da zagovara sv. Antuna i da će ga naći. Ovaj joj je odgovorio da nije sv. Antun lovački pas, pa da traži briktaš.

I spomendan sv. Antuna Padovanskog (13. lipnja) obilježen je nekim postupcima koji ga povezuju sa stokom. Primjerice, u Pavićima spominju zabranu rada sa svojom stokom na svojoj zemlji (moglo se sa svojom stokom raditi na tuđoj zemlji, dobrovoljno), dok u Krivom Putu, Veljunu i Podbilu ističu zabranu samarenja konja na taj dan, što bi značilo zabranu bilo kakvoga rada s njima. Također se spominje zabrana bilo kakvoga rada na zemlji. ${ }^{44}$ Kazivači ne znaju zašto postoji ta zabrana, no ne vjeruju da bi se njezinim kršenjem dogodilo kakvo zlo. Ističu da to čine zato što su i njihovi stariji članovi obitelji tako radili.

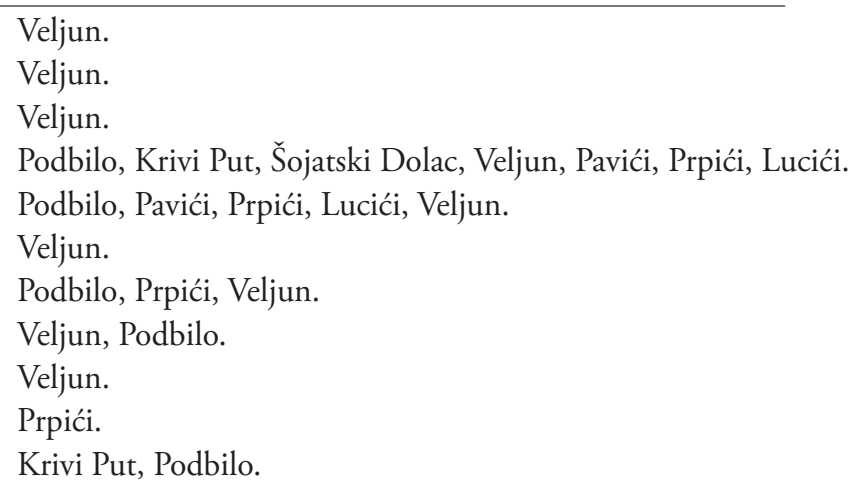


U Krivome Putu kazivači spominju jedan postupak na spomendan sv. Antuna Padovanskog koji je u nekim pojedinostima sličan onome navedenom ranije, u vezi sa sv. Jurjem. ${ }^{45}$ Krivopućani, naime, navode da se dan uoči Sv. Antuna Padovanskog skuha zelje i meso. Zelje se sljedeći dan, na Sv. Antuna, daje stoci, a rasolom od toga jela namažu joj se njuške. Postupak se provodi, kako se vjeruje, protiv ugriza zmije ili protiv bilo čega od čega bi stoka mogla uginuti. Kazivači ne znaju za kakvo objašnjenje toga postupka, već ističu da vjeruju u njegovu djelotvornost. Posjednici stoke postupak provode i danas, osobito, kako navode Krivopućani, oni stariji.

\subsection{SV. ILIJA}

Sveti Ilija je u vjerovanjima povezan s gromovima, no samo ga jedan kazivač iz Šojatskoga Dolca smatra $\checkmark$ zaštitnikom od groma. U pravilu ga doživljavaju opasnim svecem koji gromom pali i ubija ${ }^{46}$ i uzrokuje štetu ${ }^{47}$. Ne može se zaštiti od sv. Ilije, on ide svuda po nebesima..$^{48}$ On je najopasniji [svetac]. Đaba granate. Kad on pukne, ode sve. ${ }^{49}$ On di pride, on satra. ${ }^{50}$ Vjeruje se, dakle, da kad bljesne munja i udari grom, to puca sv. Ilija. ${ }^{51}$

Sv. Ilija, prema vjerovanjima, proizvodi gromove, a zašto to radi, tumači se raznoliko. U osnovi tih tumačenja uglavnom je samo jedan razlog: ljutnja sv. Ilije. ${ }^{52}$ Kako se to u jednom tumačenju paradoksalno navodi, svetac je ljutit jer ne zna kad mu je imendan, a nitko mu to ni ne želi reći jer bi sve zapalio slaveći. Stoga mu to kažu nakon njegova spomendana. ${ }^{53}$ Ljutit može biti i stoga što se ne štuje njegov dan, odnosno što se taj dan radi. ${ }^{54}$ Nadalje, sv. Ilija je ljutit i zbog toga što mu zapinje kotač dok vozi kola po nebu. ${ }^{55}$ Neki kazivači ne spominju ljutnju sv. Ilije, a nastanak groma tumače samo njegovom vožnjom kolima po nebu. ${ }^{56}$ Jedan Podbilar navodi pak vjerovanje da grmi onda kad sv. Ilija mijenja konje.

Za očekivati je, u skladu s ovim vjerovanjem, obraćanje sv. Iliji u slučaju grmljavine, odnosno nevremena. Vjerovanje se doista potvrđuje u iskazima koji se za vrijeme grmljavine govore, primjerice: Stani sv. Ilija. Nemoj pucat, ubit ćeš me ${ }^{57}$ ili Bože oslobodi sve, poubijat će Ilija sve!. ${ }^{58}$

Sam dan sv. Ilije (20. srpnja) posebno je opasan jer zna dobro grmiti. ${ }^{59}$ Stoga, kako se navodi, osobito na taj dan vrijede zabrane nekih vrsta poslova. Prema nekima, na Sv. Iliju ne smije se ništa raditi ${ }^{60}$ ili se ne smije spremati kuću ${ }^{61}$. No najčešće se navodi da je zabranjeno nalagati sijeno na voz i stavljati ga u pod (tavan $)^{62}$ te

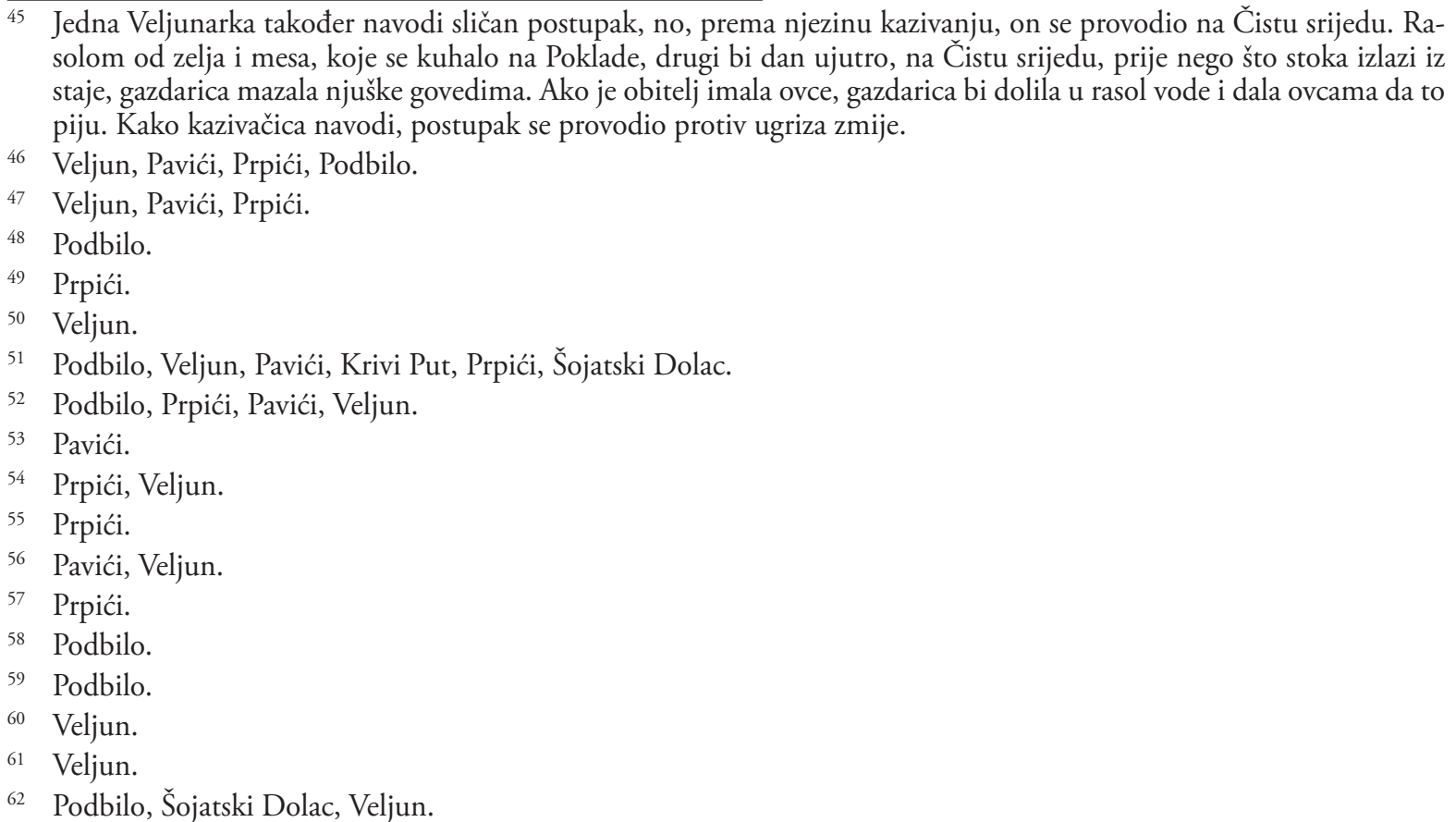


nasađivati stožina ${ }^{63}$. Vjeruje se, naime, da će u suprotnome udariti grom ${ }^{64}$ i zapaliti sijeno ili štalu ${ }^{65}$. Osim toga, mogu se dogoditi i kojekakve druge nezgode, primjerice da grom ubije blago. ${ }^{66}$ Važno je samo, kako se navodi, da se stožina nasadi bar dan uoči spomendana sv. Ilije, a sijeno se taj dan smije slagati u stog. ${ }^{67}$ Ipak, neki ističu da se ni to ne smije. ${ }^{68}$

No, u Šojatovu Dolcu i u Veljunu zabrana rada sa sijenom i stožinom zbog, kako se vjeruje, opasnosti od groma, vrijedi i sljedeća dva dana nakon spomendana sv. Ilije ${ }^{69}$ : na Sv. Danijela i Sv. Mariju Magdalenu (Mandalena). Sva tri dana zajedno nazivaju ognjenim danima.

Brojni su stanovnici ${ }^{70}$ krivoputskog područja navodili poznate im konkretne slučajeve nepoštivanja navedene zabrane na dan sv. Ilije i posljedice njezina kršenja. Primjerice:

1. Bilo je dosta slučajeva. Na Iliju je Marjanu pšenicu zapalilo, već je snopove napravio (Veljun);

2. Sedmi, e. Dvadesetoga, čini mi se. Baš nije se, ovaj, rado išlo sijeno slagat. Ja znan, jednu godinu smo mi - sunce je sjalo - išli smo kupit sijeno. I najedanput... a tata je...ne znan kako bi ja tebi objasnila, za stog sadivat... onaj kolac. Stožer, stožer onaj. (...) Tata samo zabije u zemlju - ono zagrmi! Znaššsta! Ko ono šta se reče - grom iz vedra neba. Mi smo pobigli u gaj da će nas grom(...) Nije, velim ti, nije on [otac] to, nije on baš to puno vjerova, ali tako je negdi dobio par opomena, onda više da je bija suzdržan, znaš? E. Pa smo mi znali uvik reč: 'Kako je bilo kad smo bili u Gromovini?'. Ta se livada zove Gromovina. Tu valjda je grom nekada opalio, pitaj Boga prid koliko godina, ili što. I baš u toj Gromovini kad smo bili. Onda smo kupili sijena. Onda je bilo slućajeva di se sijeno palilo. Sad da li je ko zapalio, da li je munja zapalila... pričalo se to za sijeno. Baš za svetog Iliju (Veljun);

3. (...) I ja, Ilinje je bilo, i ja ću njima vozit sijeno, da natovarimo voz sijena i vozit ćemo ga. I veli meni Mate: 'Anka, kolko se može natovarit?' Ja velim: 'Nisu baš konji za uzbrdo, ako je jako uzbrdo, a danas je i Sv. Ilija.' I mi smo vidili, zmija je baš bila u sijenu, kad smo ga prevrtali. I mi smo natovarili sijeno. Sad da je to moj did vozija, možda bi i drukčije bilo. On je muškarac. I ja velim: 'Nećemo puno natovarit.' Ali njegova žena, ona je više ko muško, ona veli: 'Samo ćemo mi natovarit.' I mi smo natovarili to sijeno. Već blizu noć se... to ovako malo uzbrdo. I neće konji da voze, pa neće. Jedan amo, jedan tamo. Pa nije to tolko bilo previšse. Da je bija did, to bi bilo izvukli. I opet istovarimo mi po, i opet neće. Istovarimo sve, neće ni praznih kola. Uzjašimo na konja i ostavimo sve gore u šumi... Ja sam rekla: 'To ti je kriv sv. Ilija.' A je li bilo to, je li... Ni kile nismo vozili, nego ostavili i došli s konjin kući. I onda se on na ovu ženu, majko moja... 'to si ti kriva što si vikala da neka natovarimo više.' Jesu se konji uspuntali, vrag zna što je bilo, ali uglavnom nismo dovukli niš. Ja rečem: 'To je sv. Ilija, nismo ga trebali natovarit na Sv. Iliju' (Podbilo).

Tuđe ili vlastito nesretno iskustvo rada sa sijenom (ili stogom) na dan sv. Ilije, koje je sadržano i u navedenim pričama, čini se primarnim razlogom i današnjeg poštivanja navedene zabrane na ovaj dan. $U$ kazivanjima se iščitava strah od ovoga sveca. On [sv. Ilija] batina, nije zgodno s njim se igrat. ${ }^{71}$ Taj je strah osobito razvidan u izjavi: Ako je sv. Ilija taj dan pogodija, taj nije sigurno, ni njegovo pokoljenje to radilo. ${ }^{72}$ Uporište u ovome vjerovanju i u ispravnosti poštivanja zabrane kazivači nalaze i u tome što su tako činili i stari ljudi. ${ }^{73}$

63 Podbilo, Krivi Put, Šojatski Dolac, Veljun, Pavići, Prpići.

${ }^{64}$ Podbilo, Krivi Put, Šojatski Dolac, Pavići, Prpići.

65 Podbilo, Krivi Put, Veljun, Pavići, Prpići, Šojatski Dolac.

66 Šojatski Dolac, Veljun.

${ }^{67}$ Krivi Put, Šojatski Dolac, Veljun, Pavići.

68 Veljun, Prpići.

69 Šjojatski Dolac, Veljun.

70 Šojatski Dolac, Veljun, Prpići.

71 Veljun.

72 Veljun.

73 Šojatski Dolac, Krivi Put, Veljun. 


\subsection{SV. NIKOLA}

Geti Nikola (6. prosinca) kao zaštitnik putnika prisutan je u vjerovanju kod samo nekoliko kazivača

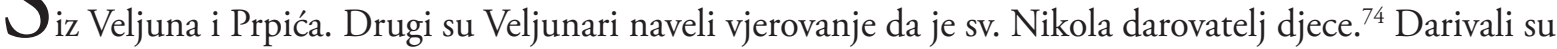
svoju djecu u čizmice na prozoru, a darove su i sami, na jednak način, dobivali od svojih roditelja.

\subsection{SV. LUCIJA}

Ta gotovo cijelom području Krivoga Puta vjeruje se da je sveta Lucija zaštitnica od bolesti očiju. ${ }^{75}$ 1 Prema predodžbama kazivača, ova svetica nosi oči na tanjuru. ${ }^{76}$ Kako navode pojedini kazivači, u vjerovanjima joj se dodjeljuje uloga zaštitnice očiju jer se pretpostavlja da je i sama bila bolesna na oči ili je nekoga ozdravila od takve bolesti ${ }^{77}$ ili pak stoga što su joj iskopali oči i stavili na tanjur ${ }^{78}$.

Na dan sv. Lucije (13. prosinca) odlazilo se na misu, jer svećenik tada, prema kazivanjima, križa i govori znaksv. Lucije što kazivači tumače dobrim radi očuvanja zdravlja očiju. ${ }^{79} \mathrm{U}$ Pavićima navode da su bolesni na oči postili dan uoči spomendana sv. Lucije.

Dan je ispunjen i zabranama nekih postupaka. I danas se na spomendan sv. Lucije ne šije, ne krpa i ne plete. ${ }^{80}$ Jedan je Veljunar naveo i zabranu pranja odjeće ističući priču kako je jedna žena opomenula mladu snahu da ne pere odjeću jer je dan sv. Lucije, a ova joj je odgovorila da nema veze jer je Lucija slijepa, pa je neće vidjeti: Dok Luca dokljuca, ja ću veš oprat. No, zbog nepoštivanja zabrane, snaha je, prema kazivanju, ostala slijepa. Isti kazivač navodi da uopće nije uputno raditi na spomendan sv. Lucije.

\subsection{KLJUČNI DANI U GODINI}

$\mathrm{N}$

a području Krivoga Puta spominju se još neki sveci, odnosno njihovi spomendani, koji su ključni u odvijanju poljoprivredne godine. Svecima, koji se tako spominju, u vjerovanju nisu dodijeljene zaštitničke uloge, nego ih se isključivo vezuje uz dane kada mještani započinju ili svršavaju neke poljoprivredne obveze. U Podbilu, primjerice, jedan od takvih dana je spomendan sv. Vida (15. lipnja) do kada mora biti zasijan kupus (prisod), a k tomu se na taj dan ne smije kositi, nego na Petrovu (29. lipnja). Za Krivopućane je također važan dan sv. Martina (11. studenog) jer se tada prestaje s lovom i poljoprivrednim radovima, o čemu govori izreka: Sv. Martin, pušku na klin, vole pod pod [tavan], jaram na pod. ${ }^{81}$

Pojedini su spomendani svetaca i ključni dani u pučkoj meteorologiji, kada se predviđaju klimatske promjene, važne za odvijanje gospodarske godine. Mnoštvo se takvih dana spominje i u istraženom području: Sv. Luca [13. prosinca] na vratima kuca ${ }^{82}$; Sv. Kata [25. studenog] zatvara vrata ${ }^{83}$; Sv. Matija [24. veljače] led razbija ${ }^{84}$; Vid moči, Petar suši ${ }^{85}$ što objašnjava ranije navedenu zabranu kosidbe na Vidovo i njezin početak na Petrovo.

74 Ovi, kao i oni koji sv. Nikolu doživljavaju zaštitnikom putnika danas su sedamdesetogodišnjaci.

75 Podbilo, Krivi Put, Šojatski Dolac, Veljun, Pavići.

76 Pavići, Šojatski Dolac, Veljun.

77 Podbilo.

78 Veljun.

79 Krivi Put, Šojatski Dolac.

80 Podbilo, Krivi Put, Pavići, Šojatski Dolac, Veljun.

81 Krivi Put, Podbilo, Pavići, Veljun.

82 Krivi Put, Podbilo.

83 Krivi Put, Podbilo, Šojatski Dolac.

84 Krivi Put, Podbilo.

85 Podbilo, Krivi Put. 
Ovdje pripadaju i već navedene izreke povezane sa sv. Josipom: Sv. Josip drvo kuca, od drveta kora pu$c a^{86}$ i $S v$. Josip puc, drvo $k u c^{87}$ koje su povezane sa široko rasprostranjenim vjerovanjem na gotovo cijelom području Krivoga Puta da je sv. Josip zaštitnik šume, odnosno šumski svetac koji na Josipovo (19. ožujka) kuca čekićem o stabla unoseći tako u njih mezgru (vegetaciju), što se vremenski podudara s bujanjem prirode $\mathrm{u}$ to doba godine. Značenjski sličnim doima se i već spomenuto proricanje o budućem vremenu o Sv. Jurju, prema kojemu dolazak sv. Jurja na zelenom konju donosi rodnu godinu, a na crnom lošu i nerodnu. ${ }^{88}$ Kazivači, zapravo, gledaju u šumu (goru) je li prozelenila ili nije. ${ }^{89}$

U Veljunu na Josipovo i proriču: Sv. Josip snigom posip. Ako ga nema, on ga sprema.

\section{ZNAČAJKE ŠTOVANJA SVETACA ZAŠTITNIKA}

$\mathrm{P}$ ri istraživanju vjerovanja u svece zaštitnike u pučkoj pobožnosti na području Krivoga Puta pokazalo se, kao što sam već navela, da najveću popularnost među njima ima Majka Božja Snježna. Ona ima dominantnu ulogu ne samo u iskazima o osobnom svecu zaštitniku, nego je i važna točka u oblikovanju identiteta zajednice, a njezin je spomendan središnji društveni događaj u godišnjem ciklusu Krivopućana.

Brojna kazivanja, ali i praćenje proslave blagdana Majke Božje Snježne, ukazala su na to da mu većina Krivopućana pridaje važnost zbog prigode za druženje i zabavu. Usprkos takvom viđenju, neki kazivači za ovaj događaj rabe izraz zavit (Kulišić i Vuković 2004:246; Kulišić i Vuković u ovom zborniku). Valja istaknuti da govor Krivopućana o Majci Božjoj Snježnoj i u kontekstu druženja i zabave ne umanjuje njihovu pobožnost, jer prema njima je i ova „izvanpobožna“ dimenzija obilježavanja blagdana važan segment štovanja svetice koju nazivaju našom zaštitnicom. I pobožnost sama, dakako, doprinosi blagdanskom ozračju i nije zanemariv blagdanski motiv za kazivače, no činjenica je da na razini zajednice taj motiv uzmiče pred onim izvanpobožnim. Primjer procesije (ibid. 248, 256) to lijepo svjedoči: njezino oblikovanje emotivno je najsnažniji trenutak proslave, no istodobno da bi se očuvala njezina svečanost itinerar je skraćen samo na ophod oko crkve jer su prostor neposredno uz crkvu zauzeli štandovi i pečeni janjci.

Također sam već navela kako Majka Božja utječe na slabiju prisutnost ostalih svetaca kao osobnih zaštitnika u pobožnosti Krivopućana, no slično se događa i u mnogim drugim lokalitetima osobito kada se u blizini nalazi neko veće Marijansko svetište (Belaj, M. 2006:249).

Ostali sveci zaštitnici koji su prisutni u životu Krivopućana također odražavaju svojevrstan identitet zajednice - onaj gospodarski. Većina svetaca koji se ovdje spominju povezani su s onim granama gospodarstva koje su značajne za područje Krivoga Puta: stočarstvo (sv. Antuna i sv. Juraja povezujemo sa stokom), poljoprivreda (sv. Marka i sv. Juraja dovodimo u vezu s rodnošću) i šumarstvo (sv. Josip zaštitnik je šume). Ovim se svecima u vjerovanju izravno pripisuje uloga osiguranja boljitka u gospodarstvu ili se njihova veza s gospodarstvom posredno iščitava u nekim postupcima ili zabranama na njihov spomendan. Zanimljivo je dodati da je stočarstvo, barem je donedavna bilo, temeljna grana privređivanja u ovome kraju, a upravo su sv. Juraj i sv. Antun Padovanski, povezani sa stokom, prema iskazima kazivača najomiljeniji među svecima (u okviru dulije).

Nadalje, promjene u načinu života odražavaju se i na štovanje svetaca. Primjerice, prestankom uzgoja stoke nema više potrebe za svecom koji je pomagao u ovoj sferi života, što su isticali i sami Krivopućani. Promjene u štovanju sv. Antuna Padovanskoga razvidne su i u pobožnosti jedne kazivačice iz Podbila. Kako sam već gore navela, ona je štovanje sv. Antuna Padovanskog s ulogom zaštitnika stoke preuzela od svoje majke i nastavila je i sama s istim razlogom zazivati ovoga sveca. $S$ prestankom uzgoja stoke nestala je

86 Prpići.

87 Podbilo.

88 Krivi Put, Podbilo, Pavići, Prpići, Veljun.

89 Krivi Put, Podbilo, Veljun. 
njezina potreba za ovakvom pomoći sveca, no ne i potreba za tim svecom. Ona mu je, prema prigodama, dodjeljivala druge uloge, pa ga je primjerice zazivala kad je rađala.

Slično o odražavanju gospodarskog identiteta kroz štovanje svetaca zaštitnika piše i W. A. Christian za španjolsku dolinu Nansa (1989:60).

Christian također piše da sveci koji su važni za zajednicu imaju svoju čvrstu poziciju u okolišu - to su likovni prikazi bilo u kapelama, bilo u župnim crkvama (Christian ih naziva shrine images). Također navodi da ti prikazi nisu jedinstveni u smislu naziva i izgleda, ali ih vjernici doživljavaju posebno moćnima - u njima vide osiguranje vitalnih aktivnosti grupe (ibid. 44).

Ovdje bih dotaknula problem povezivanja crkvenih prikaza svetaca sa štovanjem tih svetaca puku. Posebice povjesničari umjetnosti u svojim radovima ističu tu vezu. Primjerice Anđelko Badurina u jednom radu obrađuje učestalost svetačkih patronata na području nekadašnje Dubrovačke Republike i u Istri na temelju učestalosti titulara odnosno hagiotoponima uopće (usp.1988-1989), a Milan Ivanišević navodi: Štovanje određujemo po naslovniku crkve, samostana i oltara, po moćima i po bogoslužnim odredbama s pripadajućim knjigama (1994:398).

Zaključivanje o prisutnosti svetaca u pučkoj pobožnosti na temelju njihovih likovnih prikaza u crkvama ili na temelju popisivanja titulara razumljiv je postupak za povjesničare umjetnosti. No, istraživanja svetaca zaštitnika u pobožnosti Krivopućana ukazuju i na moguće propuste takvoga pristupa. Primjerice, Krivopućani navode da im je najbliža crkva sv. Ilije u Sincu, a Sv. Jurja u Senju, ali pobožnost kakvu su opisali prema ovim svecima ne iskazuju u tim crkvama. Sveci Josip, Juraj, Marko, Ilija, Nikola i Lucija nemaju svoje materijalizacije u krivoputskoj crkvi, no ipak su prisutni u pobožnosti Krivopućana. Također, ne smije se zanemariti mogućnost da neki kip ili slika u crkvi nema kontinuiranog udjela u pobožnosti puka. Te činjenice ukazuju na važnost samih vjernika kao izvora za spoznavanje pobožnosti čiji je on protagonist.

Kada govorimo o štovanju svetaca u smislu dulije na području Krivoga Puta neki su se sveci, na razini sadržajnosti iskaza o njima, pokazali omiljenijima od drugih. U pokušaju interpretacije krenut ću od pobožnosti svecima koje se, prema kazivanjima, čine sadržajnijima od drugih, u smjeru onih manje sadržajnih.

Sv. Juraj je u vjerovanjima Krivopućana, zaštitnik polja koji donosi plodnost zemlji, a njegov se dan obilježava zabranom oranja vlastite zemlje i proricanjem o rodnosti godine. Osim toga, vjeruje se i da je zaštitnik stoke, a s tim u vezi njegov se dan obilježava blagoslovom stoke.

Prema predaji, sv. Juraj Kapadocijski bio je visoki rimski časnik koji je, zbog toga što se nije htio odreći kršćanske vjere, bio mučen i pogubljen 23. travnja 303. godine. Štovanje sv. Jurja proširilo se već u 5. st. i, iako je papa Gelazij 496. godine odbacio njegov životopis kao apokrifan, ono nije u puku prekinuto. Sv. Juraj je na Drugome vatikanskom koncilu bio skoro izbrisan iz rimokatoličkoga kalendara zbog povijesne neutemeljenosti, no vjerojatno su njegova popularnost u puku i zaštitništvo nad nekim narodima (primjerice, Englezi) koji crkveno nisu sjedinjeni s Rimom, utjecali na to da se ipak zadrži. Kako je i poznato, sv. Juraj najčešće se prikazuje kao vitez s konjem koji probada zmaja. Motiv je nastao u 11. st., a uvršten je u Legenda aurea iz 13. st. Jacoba iz Voraginea. Gradu Cireni u Libiji prijetio je strašan zmaj. Stanovnici grada svakodnevno su mu žrtvovali dvije ovce, kako se ne bi okomio na njih. Kad je ovaca ponestalo, zmaj je zatražio ljudske žrtve. Jednoga je dana kocka pala na kraljevu kćer. Čekajući zmaja na obali, ona se molila i tad se pojavio sv. Juraj koji je zmaja ubio. Nakon toga su se svi stanovnici grada pokrstili. (Gorys 2003:203-204, Schauber i Schindler 1995:174-175, Belaj, V. 1998:169).

Iako bi poznavanje ove predaje moglo povezati sv. Jurja sa stokom, odnosno s ovcama, ili bi ga pak njegov poznati prikaz na konju mogao staviti u ulogu zaštitnika konja, nisam dobila izravne potvrde da su predaja ili prikaz utjecali na popularnost sv. Jurja, kao zaštitnika, u ovome kraju. Štoviše, kršćanska predaja ovdje uopće nije relevantna ako se uplete vjerovanje Krivopućana u Jurja kao donositelja plodnosti. Prema tome je li gora prolistala ili nije, stanovnici prosuđuju je li sv. Juraj došao na zelenom ili na crnom konju. O tome će ovisiti, kako su naveli, i rodnost gospodarske godine koja slijedi. Postupci koji se izvode 
na Jurjevo te postojeća vjerovanja i zabrane među kazivačima objašnjavaju se time što je to, primjerice, dobro za očuvanje stoke od bolesti i drugih nedaća ili jer se to „oduvijek radi” i „oduvijek se tako vjeruje”. No, iako kazivači povezuju svoje postupke i vjerovanje s kršćanskim svecem Jurjem, i doživljavaju ih kršćanskima, objektivno ta veza ne postoji. Lik sv. Jurja našao se u postupcima i vjerovanjima koja prema svojemu podrijetlu nisu kršćanska. V. Belaj navodi da u folklornim tvorbama poput običaja možemo slutiti krhotine starih mitova i obreda, razna "praznovjerja” koja mogu (ali ne moraju) potjecati iz starijega, već rastočenoga vjerskog sustava... Tek rijetki stariji zapisi pjesama, riječi, mjesnih imena svjedoče da u tome gradivu doista smijemo očekivati kontinuitet koji traje kroz duga stoljeća (Belaj, V. 1998:37). Opsežne studije o mitskoj pozadini nekih jurjevskih običaja i vjerovanja ukazuju, naime, na njihovo pretkršćansko podrijetlo (usp. Belaj, V. 1998). Prema tim studijama, Juraj je ukraden Perunov sin i čuvar ovaca boga stoke Velesa koji se kao personifikacija dana vraća (na Jurjevo) i donosi plodnost (ibid. 168-206, 349). Pučka praksa i vjerovanja u Krivome Putu u vezi sa sv. Jurjem u (preostalim) blijedim naznakama upućuju na svoje pretkršćansko podrijetlo, samo što je u takvim postupcima i vjerovanjima tijekom stoljeća kršćanstva glavnim likom postao sv. Juraj. Ujedno je, kako se čini, spominjanje kršćanskoga sveca u okviru postupaka i vjerovanja koji postoje jer je tako „oduvijek”, dostatno “opravdanje” da Krivopućani svoje postupke i vjerovanja shvaćaju kršćanskima.

$\mathrm{Na}$ popularnost sv. Jurja svakako je utjecao i smještaj njegova spomendana u kalendaru. Etnolog Milovan Gavazzi pisao je, imajući na umu hrvatske običaje uopće, da se Jurjevo često i izrazito shvaća kao pravi početak proljeća, više nego Josipovo ili 1. svibnja, a k tome, još i više kao početak kućanstvene ili gospodarske godine (Gavazzi 1988:41). U to se uklapaju i kazivanja iz Krivoga Puta prema kojima se dan sv. Jurja povezuje s poželjnim buđenjem prirode u ovo doba godine, odnosno s proljećem, s naglašenom gospodarskom svrhom. Vrednovanju proljeća kao uskrsnuća prirode, navodi Eliade, prethodilo je religijsko iskustvo obnavljanja Svijeta. Misterij periodičnog obnavljanja Kozmosa dao je proljeću religiozno značenje. Uostalom, prirodni fenomen proljeća i pojave vegetacije nije u obredima vegetacije uvijek važan, već je mnogo važniji znak koji navjeśćuje kozmički misterij. (...) To je znak predstojećeg uskrsnuća vegetacijskog života, svjedočanstvo da se misterij zbio, da će proljeće uskoro doći (2002:92).

Sv. Antunu Padovanskome se u vjerovanju Krivopućana također dodjeljuje uloga zaštitnika stoke u prvome redu, te mu pojedini kazivači dodjeljuju još neke uloge. Kao ni kod sv. Jurja, tako se ni kod sv. Antuna Padovanskog putem predaje o svecu ne može objasniti njegova uloga zaštitnika stoke.

Sv. Antun Padovanski (Lisabon, 1195. - Arcella kraj Padove, 1231.) spada među najveće odličnike Katoličke crkve, a o popularnosti ovoga sveca slikovito piše fra B. Z. Šagi: doklegod bude religije bit će i sv. Antuna (1996:122). Proglašen je svetim samo jedanaest mjeseci nakon smrti, u dosada najkraćem procesu kanonizacije. Čašćenje sv. Antuna Padovanskog prvo se proširilo po Padovi i u franjevačkom redu, a od 16. st. časti se u cijeloj Crkvi. Antunova bazilika u Padovi jedno je od najposjećenijih hodočasničkih mjesta. Najčešće se prikazuje kao mladi franjevac s ljiljanom i knjigom, $s$ djetetom Isusom, $s$ plamenom, kako drži propovijed ribama, te njegovo čudo s hostijom (Schauber i Schindler 1995:290-293, Gorys 2003:59-60). Potonji je prikaz jedino što ga povezuje s domaćim životinjama. Prikaz je nastao na temelju predaje da je sv. Antun Padovanski pokazao hostiju ogladnjelom magarcu jednoga heretika, no magarac ju je odbio, a potom pokleknuo. Nakon toga heretik se obratio. No, ni ova predaja, kao ni bilo što izravno povezano sa sv. Antunom Padovanskim, sudeći prema navodima kazivača, ne objašnjava njegovu popularnost u liku zaštitnika stoke, niti vezu ovoga sveca sa stokom uopće.

Tu bi, međutim, mogao pomoći sv. Antun Opat, čiji je spomendan 17. siječnja. On je u mnogim krajevima Hrvatske u pučkom vjerovanju prihvaćen u ulozi zaštitnika stoke (Belaj, M. 2006:82-83). Predaje o ovome svecu, a osobito njegov prikaz sa svinjom zbog čega ga se u puku često naziva i Antun svinjski, zasigurno su utjecale na to da mu se u pučkoj pobožnosti dodijeli uloga zaštitnika stoke. I prema srednjovjekovnoj diferencijaciji svetaca prema ulogama, pastirska uloga primarno pripada sv. Antunu Opatu. Ipak, kad se govori o popularnosti svetaca u hrvatskoj pučkoj pobožnosti, teško da se koji može „nositi“ sa sv. Antunom Padovanskim. Sv. Antun Padovanski, svetac svega svijeta, najpopularniji je svetac i u hrvatsko- 
me puku, a njegov biljeg hrvatske pučke religioznosti dolazi odmah iza marijanskoga, a u nekim krajevima možda i ispred (Šagi 1996:114). Sv. Antun [Padovanski] je najizrazitiji pučki model sveca-zaštitnika u svim ljudskim potrebama (ibid. 121). Stoga je očito da se uloga zaštitnika stoke sa sv. Antuna Opata ponegdje u vjerovanju prenijela na popularnijeg imenjaka, sv. Antuna Padovanskog, ionako u hrvatskoj pobožnosti vrlo „svestranog“ sveca. Na to ukazuje i gradivo iz drugih hrvatskih lokaliteta (Belaj, M. 2006:82-88, 193; Jardas 1957:38-39, 69), kao i iz nehrvatskih krajeva (Kuret 1989/1:377-378; Behar 1990:99-102). Takav prijenos može rezultirati stapanjem dvaju Antuna u jednoga čiji se dan onda obilježava dvaput godišnje ili pak potpunim prijenosom pastirske uloge na sv. Antuna Padovanskoga i odbacivanjem sv. Antuna Opata iz pobožnosti (Belaj, M. 2006:193-194, 254-255). Istraživanje u Krivome Putu jasno je pokazalo potonju mogućnost, a ona je potvrđena i na obližnjem području Krasna (ibid. 85-86, 255).

Od ostalih uloga koje se u Krivome Putu pripisuju sv. Antunu Padovanskom navodi se još samo, u jednome kazivanju, uloga pomoćnika žena i djece pri porodu. Pripisivanje takve uloge sv. Antunu Padovanskom moglo bi se tumačiti pučkom interpretacijom popularnog prikaza ovoga sveca kako drži dijete - Isusa ili prikazom ovoga sveca sa srcem u plamenu koji simbolizira ljubav prema Isusu i njegovoj majci Mariji. Ponešto od izraza osobne pobožnosti zabilježeno je i tijekom obilježavanja blagdana Majke Božje Snježne. Iako bi se praćenjem događanja pri obilježavanju blagdana sv. Antuna Padovanskoga dobila potpunija slika o njegovoj ulozi u osobnim pobožnostima, upravo začuđuje nedostatak takvih potvrda u kazivanjima. Ona govore da ovaj „svestran“ i „univerzalan“ svetac nije našao većega odraza u pobožnostima kao osobni zaštitnik. No, takve su pobožnosti u Krivome Putu u prvome redu usmjerene prema Majci Božjoj, koja je u tom segmentu očito zasjenila ostale svece, pa i sv. Antuna Padovanskoga.

Vjerovanja povezana sa sv. Ilijom prema svojoj sadržajnosti ukazuju također na vrlo živu prisutnost ovoga sveca u pobožnosti Krivopućana. Predodžbe prema kojima sv. Ilija stvara gromove vozeći se kolima po nebu izravno se mogu povezati s biblijskom predajom o smrti ovoga starozavjetnog proroka koji je na ognjenim kolima živ uzašao na nebo $(2 \mathrm{Kr}, 2,11)$. On također, prema Bibliji, upravlja vremenom (1Kr, 17,1; 2Kr, 1, 9-13; Sir 48,1-3). No, sv. je Ilija u predodžbama Krivopućana opasan svetac, koji iz ljutnje gromom puca te uzrokuje štetu i ubija: Kad on pukne, ode sve / On di pride, on satra / On batina, nije zgodno s njim se igrat / Bože oslobodi sve, poubijat će Ilija sve! / Nemoj pucat, ubit ćě̌ me. Prema kazivanjima, sv. Ilija se ljuti jer se ne štuje njegov dan ili ne zna kad mu je imendan ili zato što mu je zapeo kotač kola. Dok se kod drugih svetaca, naime, govori o zaštitničkoj ulozi, dobrohotnosti, pomoći u rješavanju nedaća i zla, osobine sv. Ilije u prvome redu upućuju na njegovu moćnost. On je osvetoljubiv svetac koji u ljutnji nemilosrdno rabi svoje oružje - grom i može ubiti i čovjeka. U takvome vjerovanju o sv. Iliji i u osobinama koje mu se pridaju naslućuju se primjese nekršćanskoga podrijetla. Kao i kod sv. Jurja i ovdje se pozivam na rad V. Belaja (1998). On, naime, navodi kako se sv. Ilija može javiti u kršćanskim interpretacijama priče koje sadrži shemu, na praslavenskoj razini, o poganskome bogu, gromovniku: Perunu (koji) ubija (goni) munjom (gromom) Velesa (zmiju). U takvoj shemi, navodi Belaj, mogu se mijenjati osobe koje sudjeluju u zbivanjima, rekviziti kojima se izvršava radnja pa čak i sama radnja, a da priča ostane ista. Posve je isto, kaže li se da je Perun ubio Zmiju ili sveti Ilija Vraga. Razlika je samo u razini na kojoj se priča ostvaruje (ibid. 70). U pričama o sv. Iliji nalazi se ulomak mita koji je tijekom dugih stoljeća dobio kršćansku presvlaku (ibid. 69). I Perun i Veles, oba su bila čovjeku opasna (...) Suprotno nekim očekivanjima, nema nikakvih indicija da bi Praslaveni imali dualističku predodžbu o bogu dobra i bogu zla (ibid. 87). U spomenutom se vjerovanju u Krivome Putu ne nailazi na cjelovitu strukturu koja bi ga povezala s mitskom pripovijesti - u prvome redu nedostaje protivnik, osim ako to nije zmija u sijenu, spomenuta u gore navedenom kazivanju iz Podbila o događaju na dan sv. Ilije. No, sv. Ilija prikazan je kao ubojit svetac koji se u osvetoljubivosti koristi gromom. Uzroci nesretnim događajima na 20. srpnja pripisuju se gnjevu sv. Ilije. Njegov je dan u krivoputskoj pobožnosti ispunjen zabranama zbog prijeteće opasnosti od groma, prema vjerovanju, Ilijina oružja. Osim toga, naglašeno spominjanje ovoga sveca kao opasnog i osvetoljubivog upućuje na to da je u sebe aposrbirao neko prijašnje božanstvo drukčijeg religijskoga sustava u kojemu se ono u odnosu na druga božanstva ne poima u opreci dobro - zlo, već u prvome redu kao izrazito moćno. 
Valja pridodati da i smještaj spomendana sv. Ilije u kalendaru pruža objektivne okolnosti pripisivanja gromovničkih sposobnosti poganskoga boga Peruna sv. Iliji i objektivan prostor razumijevanja straha od gromovničkog djelovanja sv. Ilije. Kako navodi M. Sijerković, u domovini Slavena u dijelu ljeta kojemu pripada spomendan sv. Ilije vrijeme je često olujno i promjenjivo. Često gromovito nevrijeme u tom dijelu Europe rezultat je sučeljavanja svježeg i vlažnog zraka kojega donose atlantske ciklone s ugrijanim zrakom iznad kopna. U našem južnijem podneblju, suprotno tome, druga polovina srpnja obično donosi lijepo vrijeme te je spomendan sv. Ilije kalendarski smješten u najtoplijem dijelu srpnja i godine uopće. Nevrijeme s grmljavinom u to doba godine prilično je rijetko. Stoga je, piše Sijerković, grmljavina na Sv. Iliju neuobičajeno vrijeme koje bi moglo imati neželjene posljedice. Ipak, grmljavina u to doba godine nije nemoguća pa je razumljivo zaziranje od njezinih mogućih posljedica - učestale kiše u to doba godine štete dozrijevanju raslinja (1996:121-123).

Vjerovanja u vezi sa sv. Josipom iz perspektive kazivača u prvome redu ukazuju na značenje njegova spomendana u kalendarskoj godini. Sv. Josip Nazarećanin bio je zaručnik Marije, majke Božje i Isusov poočim. Radio je kao tesar te se, prema apokrifnoj predaji, kao osamdesetogodišnjak zaručio s dvanaestogodišnjom Marijom. Kad je ona rodila sina, djetetu je, prema naputku anđela, nadjenuo ime Isus (Jošua, „spasitelj“, „otkupitelj“) (Mt 1,21). Istočna crkva štovala je sv. Josipa vrlo rano, a u Zapadnoj se štuje najranije od 6. st., a možda i tek od 9. st. Godine 1479. uveden je njegov blagdan, a od god. 1714. taj je blagdan propisan za cijelu Crkvu. Nije potpuno jasno zašto je spomendan sv. Josipa utvrđen na 19. ožujka. Neki pretpostavljaju da je to u vezi s idućim blagdanom, 25. ožujka, kada se u Crkvi slavi Blagovijest, navještaj arkanđela Gabrijela Mariji da će roditi Sina Božjega (Lk 1,26-38). Drugi pak Josipov dan povezuju s praznikom boginje Minerve, boginje rukotvorstva, koji se u starom Rimu slavio 19. ožujka. Štovanje sv. Josipa dostiže vrhunac 1870. godine kada je uzdignut u zaštitnika cijele Crkve. K tome, papa Pio XII. je 1955. godine odredio 1. svibnja kao blagdan „Josipa radnika“, čime je socijalistički Praznik rada dobio svoje kršćansko posvećenje. Na prikazima sv. Josip je bradati starac s tesarskim oruđem ili pak nosi dijete Isusa, u ruci nosi ljiljan ili putnički štap iz kojega cvjeta ljiljan (Schauber i Schindler 1995:110111; Gorys 2003:200-201).

Spomendan sv. Josipa u Krivome Putu smatraju početkom vegetativnog ciklusa, odnosno proljeća, jer, prema njihovim kazivanjima, sv. Josip udarajući čekićem unosi mezgru [vegetaciju] u stabla. No, i sv. Juraj se, kako sam gore navela, u vjerovanju povezuje $s$ dolaskom proljeća - on je zaštitnik polja koji donosi rodnost zemlji te se na njegov dan pretkazuje uspješnost gospodarske godine. Ponovit ću ovdje da je M. Gavazzi pisao da se u Hrvata Jurjevo, više nego Josipovo, shvaća kao pravi početak proljeća, i k tome više kao početak kućanstvene ili gospodarske godine (1988:41). U Krivome Putu, kako upućuju kazivanja, ova su dva sveca podijelila značenje proljetnih svetaca. Budući da je u vezi sa sv. Josipom naglašeno proljetno bujanje prirode, čini se da kazivači Josipovo doživljavaju početkom proljeća, a spomendan sv. Jurja, donositelja plodnosti, doživljavaju početkom gospodarske godine. O objektivno lošijoj prikladnosti spomendana sv. Josipa za pretkazivanje o rodnosti uopće piše i M. Sijerković. On pretpostavlja da se Sv. Josip kao ključni dan izabire radi glasovitosti svoga blagdana, te dodaje: Ožujski ključni dani ipak su slučajno nanizani, a prognostički nisu znakoviti ni značajni (1996:87), za razliku od Sv. Jurja koji je neprijeporno (...) uvelike povezan s klimatskim obilježjima toga dijela godine (ibid. 94).

Pišući o običaju cijepljenja voćaka u dijelovima Istre i Kastavštini na spomendan sv. Josipa, Branko Fučić je u potrazi za korijenima toga običaja prizvao jedan motiv iz Pseudomatejeva evanđelja koji se javlja i u kasnijim inačicama toga apokrifa, u Zlatnoj legendi te na crtežima i slikarijama Zaruka Marijinih i predaji nastaloj na temelju tog uprizorenja. Predaja govori o zarukama sv. Marije i Josipa, prema kojoj je sv. Josip prepoznat kao Marijin zaručnik po prolistalom štapu. Fučić pretpostavlja da je ovaj motiv mogao djelovati na praksu cijepljenja voćaka te da je puk vjerovao da kako je prolistao Josipov štap, analogno tome procvjetat će njihove voćke cijepljene na Josipovo (1971:338-339).

U ovome motivu mogli bi se pretpostaviti i korijeni krivoputskog vjerovanja o sv. Josipu na čiji dan počinje vegetacijski ciklus. 
Budući da stanovništvo Krivoga Puta pripada primorskoj grani Bunjevaca, zanimljivo je dodati i podatak o vezi dana sv. Josipa i voćaka zabilježen kod bačkih Bunjevaca. Bački Bunjevci, naime, obrezuju voćke dan uoči Josipova, no to se također radi i dan uoči Jurjeva (Sekulić 1986:374).

Valja još spomenuti izreku Veljunara Sv. Josip snigom posip. Ako ga nema, on ga sprema. Izreka je u vezi s mogućim klimatskim zbivanjima sredinom ožujka, kada jaki prodori hladnoga zraka donesu i snijeg (usp. Sijerković 1996:85). Sveti se Josip ovdje spominje samo u vidu svoga spomendana, glasovitijega dana u tom dijelu ožujka s kojim se povezuju navedena klimatska zbivanja.

Vjerovanja u preostala tri sveca (sv. Marko, sv. Nikola i sv. Lucija) nisu toliko sadržajna te se uklapaju u općepoznatu pobožnost na prostoru Hrvatske, bez nekih naznaka lokalnih obilježja ili odstupanja. Ipak, zanimljivo je da sv. Marka, zaštitnika polja i donositelja plodnosti u vjerovanju, spominju gotovo jedino Veljunari (još ga je samo spomenuo jedan kazivač iz Podbila), no o tome se vjerovanju govori samo na razini sjećanja. Kazivači jedva da se sjećaju procesija i blagoslova polja na Markovo, a stoga nije ni bilo moguće dobiti podrobnije podatke, primjerice, o spomenutim individualnim blagoslovima polja (bez prisutnosti svećenika).

Sv. Marko, apostol i evanđelist, umro je kao mučenik 66. ili 67. godine - njegovu smrt na lomači spriječila je jaka kiša, pa je vučen ulicama Aleksandrije sve dok nije umro. Godine 828. venecijanski su trgovci pronašli njegove kosti i dopremili ih u Veneciju. Tada upravo građena crkva (na mjestu današnje crkve sv. Marka, nastale između 1063. i 1073. god.) posvećena je ovomu svecu zajedno s njegovim relikvijama 832. godine. Prikazuje se s krilatim lavom (simbol ovoga evanđelista) ili kao evanđelist s knjigom, perom za pisanje i tintarnicom. Brojni su i prikazi njegova mučeništva i prijenosa relikvija (Schauber i Schindler 1995:181-182; Gorys 2003:272).

Iz poznatih izvora o životu ovoga sveca nije moguće razumjeti općerašireno vjerovanje u njegovu ulogu zaštitnika polja koji donosi plodnost zemlji. Procesije s blagoslovom polja na Markovo, kao izraz toga vjerovanja izvorno nisu u vezi s ovim kršćanskim svecem. One izviru iz nekog poganskog obreda (Schauber i Schindler 1995:182) koji je u kristijaniziranom obliku ušao u katolički obred. U tom kontekstu koristan je podatak da se na 25. travnja održavala rimska svetkovina povezana sa žitom, Robigalia. $\mathrm{Na}$ Prenestinskim fastima [kamenim spomenicima na kojima su zapisani kalendari] se vidi da se odvijala na petoj milji na Via Claudia u svetom gaju. Čitava je svečanost posvećena uklanjanju žitne rđe. (...) Ime božanstva koje je obitavalo u žitnoj rđi je Robigus (lat. robigo „rđa“, „bolest na žitu, snijet“), a njegova je uloga bila zaštita žita (Milićević 1990:98). Svetkovina se obilježavala procesijom do gaja boga Robigusa gdje se žrtvovao pas ili ovca (Kuret 1989/1:275).

Procesije s blagoslovom polja na Markovo dio su katoličkog bogoslužja - katoličanstvo ih je preuzelo, ali im je dalo novi sadržaj. Taj je sadržaj puk prilagodio sebi izvodeći blagoslov polja, kako navode Veljunari, i samostalno vjerujući da će tako potaknuti plodnost svojih polja.

Sv. Nikola također, kao i sv. Marko, nema većega odraza u cjelokupnoj krivoputskoj pobožnosti. Spominju ga samo Veljunari te kazivač iz Prpića kao zaštitnika putnika, a Veljunari k tome i kao darivatelja djece u okviru običaja s čizmicom.

Sv. Nikola (Patras, 270. - Mira, 345./350.), biskup iz Mire, inače je jedan od najštovanijih svetaca u Crkvi. Oko njega su snažno isprepletene povijest i predaje. Već je u 5. st. nad njegovim grobom u Miri podignuta kršćanska bazilika, uništena u potresu 529. godine, te odmah potom ponovno izgrađena. Godine 1087. talijanski su trgovci iz Mire, koju su opustošili Seldžuci, ponijeli kosti sveca u Bari gdje je potom podignuta i ovome svecu posvećena crkva. Na Istoku je ovaj svetac štovan još u 6. st., a u Rim i donju Italiju njegov je kult dospio tek u 9. st. U 10. st. kult se razvio u Njemačkoj zahvaljujući supruzi cara Otona II., carici Teofano bizantskoga podrijetla. Izgradnja crkve u Bariju utjecala je na porast njegova kulta na Zapadu. Svetac se prikazuje kao stariji biskup sa štapom, palijem i mitrom, a često s atributima koji su mu pridodani na temelju poznatih predaja o ovme svecu (Schauber i Schindler 1995:629-631; Gorys 2003:291).

Iako se to ne može reći za cijelo krivoputsko područje, sv. Nikola svoje inače općepoznate uloge zaštitnika putnika i darivatelja, odnosno u širem smislu zaštitnika djece, ima zahvaljujući kasnosrednjovje- 
kovnim predajama o njegovu životu. Primjerice, prvospomenuta uloga u vjerovanju u vezi je s predajom prema kojoj je putnike, koji su ga došli posjetiti, spasio od otrova. Otrov im je dala poganska božica Dijana kako bi se osvetila Nikoli za stablo koje je posjekao, a bilo joj je posvećeno. Druga uloga je u vezi s predajom prema kojoj je oživio školarce koje je neki gostioničar ubio i usolio ih ili kako je vratio u život dijete koje je izgorjelo na kućnome ognjištu ili pak kako je djevojkama, koje je otac želio poslati u javnu kuću da bi zaradile za miraz, noću kroz prozor ubacio vrećicu sa zlatnicima.

Običaj darivanja djece u čizmicu, kojega spominju Veljunari, pristigao je na prostor Hrvatske iz susjednih zemalja srednje Europe. Smatra se razmjerno mladim običajem na hrvatskome selu gdje je stigao iz građanske tradicije. Također, smatra se da je darivanje u čizmicu mlađa anticipacija božićnoga darivanja (Gavazzi 1988:116-117).

Sv. Lucija kao zaštitnica očiju sveprisutna je na cijelome hrvatskom prostoru. Dodjeljivanje uloge zaštitnice očiju u krivoputskoj pobožnosti, kako se i iz kazivanja čita, rezultat je predodžaba nastalih na temelju prikaza svetice koja na plitici nosi dva oka. Prikaz je nastao iz jedne kasnije legende prema kojoj si je Lucija, zavjetovana na vječnu nevinost, iskopala oči i poslala ih svojemu neželjenom zaručniku.

O životu sv. Lucije (oko 286. - 304.), mučenice iz Sirakuze, govore samo predaje. Njezino su mučenje pratila brojna čudesa, a na kraju su joj mačem odsjekli glavu. Štovanje ove svetice procvalo je u 6. i 7. st. te ponovno od 16. st. Do uvođenja gregorijanskoga kalendara, 1582. god. njezin je dan bio najkraći u godini (zimski solsticij). Stoga se ne samo na hrvatskome prostoru, nego i drugdje u Europi, odvijaju običaji u kojima važnu ulogu ima neki izvor svjetlosti (žar, svijeće), a koji, prema nekim tumačenjima, imaju korijen u pučkoj etimologiji imena sv. Lucije (lat. lux „svjetlost“, luceo „svijetliti“) (Gorys 2003:248-250; Gavazzi 1988:119). Točan dan smrti sv. Lucije nije poznat, a Crkva je s njegovim utvrđivanjem, na 13. prosinca, imala jasnu namjenu. Niko Kuret navodi da je tih dana u prosincu na prostoru sjeverozapadno od Balkana i po jugozapadnom rubu Alpa ljude strašilo žensko božanstvo, čije je prvotno pogansko ime nepoznato, a poznata je bila svim Indoeuropljanima. Ona je voditeljica duša, prije svega duša umrle djece, a kasnije i duša nerođene djece. Istodobno je lijepa i ružna, dobra i zla. U njemačkoslovenskom prostoru je, navodi Kuret, zaštitnica prelja. Kuret joj je nadjenuo ime Sredozimka. Crkva je ovoj ženskoj pošasti tame suprotstavila sveticu koja je s imenom i simbolom donosila svjetlost. Zbog ove namjene, dodaje Kuret, događaji iz njezina prvotnoga predajnog života nisu bili toliko zanimljivi koliko događaj s očima koje je svetica žrtvovala i ponovno čudesno zadobila (prema jednoj kasnijoj legendi) (1989/2:244-245, 458). U dijelu srednje Europe (Međimurci, gradišćanski Hrvati i njihovi njemački susjedi, panonski Slovenci, u južnoj Češkoj i Moravskoj te djelomice u Mađarskoj) u noći s 12. na 13. prosinca obilaze „Lucije“ i plaše djecu, stoga, zaključuje Kuret, dogodilo se da sv. Lucija nije svoju pretkršćansku suparnicu potpuno zatrla - ona joj je samo predala svoje ime. S promjenom kalendara 1582. godine početak zime pomaknut je na 22. prosinca pa se $s$ vremenom izgubilo ovakvo značenje dana sv. Lucije u puku te je, posebno u baroku, pokrenut novi val čašćenja kako bi se ponovno uspostavila vrijednost ove svetice (ibid. 245).

Zabrana šivanja, predenja i pletenja, koje se Krivopućani pridržavaju na Lucijin dan, zabilježena je na prostoru od sjeverozapada do sjeveroistoka Hrvatske te kod bačkih Bunjevaca (Belaj, M. 2006:56), no nalazimo je i drugdje, primjerice, osobito u Bosni (Gavazzi 1988:119) ili u Sloveniji (Kuret 1989/2:250-251). Ovakva zabrana vrijedi i na neke druge spomendane svetaca (Belaj, M. 2006:189), no na dan sv. Lucije zabilježena je neusporedivo češće. Budući da se ova zabrana općenito odnosi na zabranu korištenja oštrih predmeta, neki je tumače aluzijom na mač kojim je sv. Luciji odrubljena glava (usp. Gorys 2003:250). U puku je, pak, prvotni smisao zabrane strah od gubitka vida. To bi također bilo u Lucijinoj vezi sa Sredozimkom koja je, prema Kuretu, sačuvala pogansko zaštitništvo nad prediljama i predenjem, ali na račun prihvaćanja kršćanskih radnih propisa i napuštanja svojega imena (Kuret 1989/2:459).

U krivoputskim zaselcima Krivi Put i Podbilo, vezano uz sv. Luciju, navodi se izreka Sv. Luca na vratima kuca koja ukazuje da je njezin dan ključan u predviđanju klimatskih promjena. M. Sijerković navodi 
da većina izreka u kojima se ističu klimatska obilježja prosinca potječu s primorja, što ima meteorološko opravdanje u zamjetnijim promjenama vremena u ovome podneblju (1996:168).

Ostali se sveci spominju isključivo na razini svojih spomendana, a ne kao zaštitnici. Sv. Katarina i Sv. Matija isključivo imaju značenje najavljivanja klimatskih zbivanja svojstvenih dijelu godine u koji su smješteni, dok Sv. Vid, Sv. Petar i Sv. Martin imaju ulogu podsjetnika za obveze tijekom gospodarske godine. Krivoputska izreka Sv. Martin, pušku na klin, vole pod pod [tavan], jaram na pod govori o kraju svih gospodarskih radova.

Značenje dana sv. Martina zajedno s danom sv. Jurja na krivoputskom području govori i o poimanju vremena u godini uopće, poimanju čije korijene nalazimo u solarnom kalendarskom sustavu drevnih euroazijskih stočara (usp. Belaj, V. 1998:100-103). U Krivome Putu spomendan sv. Jurja označava početak gospodarske godine kada počinje ispaša stoke pri čemu ju je valjalo onda i blagoslovom zaštititi od bilo kakvih nedaća i stradavanja. Spomendan sv. Martina označava kraj gospodarske godine te početak zimskog razdoblja i mirovanja. Godina je ovim dvama danima podijeljena na dva dijela, ljetni i zimski.

Spomendani svetaca na istraženom području najčešće se vezuju uz zbivanja u prirodi. Kazivači govore o ulasku mezgre u stabla, o gori koja je prozelenila ili nije, o stoci koju na početku gospodarske godine valja blagoslovom zaštititi, o razdoblju kad se sije kupus i kad se kosi, o opasnosti od groma, o opadanju lista, trenutku spremanja svog oruđa za rad te dolasku snijega i leda. Ovakvo poimanje vremena ukazuje na ciklički protok vremena, a on nije značajka službenoga kršćanskoga poimanja vremena.

Vjerovanja i postupci sadržani u krivoputskoj pobožnosti pokazuju značajke prema kojima ih možemo svrstati u dvije osnovne grupe. U nekim se vjerovanjima i postupcima, primjerice u vezi sa sv. Jurjem, sv. Markom, sv. Ilijom i sv. Lucijom mogu prepoznati tragovi nekog pretkršćanskoga vjerovanja povezanog sa zbivanjima u prirodi koji imaju svoj kršćanski pokrov. S druge strane, vjerovanja u vezi sa sv. Josipom, sv. Antunom Padovanskim i sv. Nikolom proizašla su iz kršćanskoga okrilja, no puk ih je u primjeni interpretirao prema vlastitim potrebama. No, poznavanje podrijetla ovih vjerovanja ili postupaka s njima u vezi ne mora biti uvjet za otkrivanje njihova današnjega značenja - o kojem god se tipu vjerovanja radilo, puk ih doživljava potpuno kršćanskima, bez obzira na nekršćanske primjese. Postupci, primjerice, u vezi sa stokom na Sv. Antuna Padovanskoga i Sv. Jurja za njih su u prvome redu blagoslovi koji se izvode na kršćanski blagdan, s (u crkvi) blagoslovljenim grančicama is blagoslovljenom vodom.

Uopće, pobožnost o kojoj je ovdje riječ pokazuje zamjetan stupanj isprepletenosti kršćanskih i nekršćanskih elemenata: puk prati ustanovljene spomendane kršćanskih svetaca, no obilježava ih neovisno i neograničeno u odnosu na Crkvu. Tu mislim na nesputanu uporabu u Crkvi blagoslovljenih grančica ili vode u pučkim blagoslovima, na predodžbe o kršćanskim svecima kojima se pripisuje utjecaj u prirodnim zbivanjima i u ovozemaljskim potrebama, a koje katkad rezultiraju i zabranama odvijanja inače svakodnevnih poslova. Sa stajališta kazivača ovakvi postupci i vjerovanja odražavaju odnos prema svetome. Sveti predmeti i obredne radnje u pučkoj su religioznosti sasvim neograničeni; u svojem nejasnom osjećanju svetosti čovjek želi cijeli svoj životni okoliš posvetiti: domaće životinje, kuću, gospodarske zgrade, vrt i polje (Zorić 1991:35). Svesakralnost značajka je mitskoga svjetonazora. Prema takvom svjetonazoru, sve što nas okružuje više je ili manje prožeto svetim, uređenim, a to je posljedica djelovanja sila Reda (ili Kozmosa). No istodobno posvuda možemo uočiti djelovanje sila Nereda (ili Kaosa). U svim segmentima stvarnosti odvija se sukob između sila Reda i sila Nereda (usp. Belaj, V. 1998:24). Vjerovanje u svece zaštitnike uopće, kao i postupci i zabrane koji su u vezi sa spomendanima tih svetaca usmjereni su na rješavanje ovozemaljskih problema. [S]eljak rabi religijsko, po definiciji onostrano i izvan granica iskustva da bi poboljšao i zaštitio sebe i svoju okolinu na ovome svijetu (Čapo Žmegač 1997:106). To je ujedno, barem kako prikazano gradivo pokazuje, i osnovna svrha odnosa prema svetome i bitno obilježje pobožnosti u istraženom kraju. 


\section{LITERATURA:}

BADURINA, Anđelko (1988-1989): Hagiotopografija Istre i dubrovačkog područja. Radovi Instituta za povijest umjetnosti 12-13:59-63, Zagreb.

BEHAR, Ruth (1990): The Struggle for the Church: Popular Anticlericalism and Religiosity in PostFranco Spain. U: ur. E. Badone, Religious Orthodoxy and Popular Faith in European Society. Princeton University Press, Princeton, New Jersey, 76-112.

BELAJ, Marijana (2006): Sveci zaštitnici u hrvatskoj pučkoj pobožnosti. Doktorska disertacija, Filozofski fakultet Sveučilišta u Zagrebu.

BELAJ, Vitomir (1988): Marija u pučkim vjerovanjima Hrvata (Prolegomena jednom istraživačkom zadatku. U: ur. A. Rebić, Mundi Melioris Origo. Marija i Hrvati u barokno doba. Zbornik radova hrvatske sekcije IX. međunarodnog mariološkog kongresa na Malti 1983. godine, Radovi Hrvatskog mariološkog instituta, sv. 7-8:190-195, Kršćanska sadašnjost, Zagreb.

BELAJ, Vitomir (1998): Hod kroz godinu. Mitsk pozadina hrvatskih narodnih običaja i vjerovanja. Golden marketing, Zagreb.

BEZIĆ, Srećko (1981): Pastoralna obnova crkve i pučka pobožnost prema Mariji. U: ur. A. Rebić, Advocata Croatie. Zbornik radova hrvatske sekcije VIII. medunarodnog mariološkog i XV. marijanskog kongresa, Zaragoza, 3.-12. 10. 1979. godine. Kršćanska sadašnjost, Zagreb, 312-319.

BIBLIJA. Kršćanska sadašnjost, Zagreb, 2000.

CHRISTIAN, William A., Jr. ('1989): Person and God in a Spanish Valley. Princeton University Press, Princeton, New Jersey.

ČAPO ŽMEGAČ, Jasna (1997): Hrvatski uskrsni običaji. Golden marketing, Zagreb.

ELIADE (1970): Mit i zbilja. Matica hrvatska, Zagreb.

ELIADE, Mircea (2002 [1957]): Sveto i profano. AGM, Zagreb.

FUČIĆ, Branko (1971): Cijepljenje na Josipovo. Zbornik za narodni život i običaje južnih Slavena, sv. 45:337-339, JAZU, Zagreb.

GAVAZZI, Milovan (21988): Godina dana hrvatskih narodnih običaja. Kulturno-prosvjetni sabor Hrvatske, Zagreb.

GORYS, Erhard (2003): Leksikon svetaca. Naklada Slap, Jastrebarsko. [hrvatski prijevod i dopuna izvornika iz 1997. god.]

HOŠKO, Franjo Emanuel (2001a): Temeljni oblici štovanja svetaca tijekom povijesti Crkve. U: Franjevci i poslanje Crkve u kontinentalnoj Hrvatskoj, Kršćanska sadašnjost, Zagreb, 363-379.

HOŠKO, Franjo Emanuel (2001b): Sadržajne i povijesne odrednice razvoja i istraživanja pučke pobožnosti. U: Franjevci i poslanje Crkve u kontinentalnoj Hrvatskoj, Kršćanska sadašnjost, Zagreb, 381-401.

IVANIŠEVIĆ, Milan (1994): Ikonografija solinskih mučenika kroz stoljeća. U: ur. E. Marin, Salona Christiana, Katalog - monografija izložbe. Arheološki muzej, Split, 393-409.

JARDAS, Ivo (1957): Kastavština. Građa o narodnom životu i običajima u kastavskom govoru. Zbornik za narodni život i običaje južnih Slavena, sv. 39, JAZU, Zagreb.

KULIŠIĆ, Marija i Ivana Vuković (2004): Majka Božja Snježna u pučkoj pobožnosti na području Krivoga Puta. Senjski zbornik 31:239-260, Senj.

KURET, Niko ('1989): Praznično leto Slovencev. Knjiga 1 i 2, Družina, Ljubljana.

MILIĆEVIĆ, Marina (1990): Rimski kalendar. Latina et Graeca, Zagreb.

O'CONNOR, Mary (21999): The Pilgrimage to Magdalena. U ur. S. D. Glazier, Anthropology of Religion. A Handbook, Praeger, Westport, 369-389.

REBIĆ, Adalbert, ur. (2002): Opći religijski leksikon. Leksikografski zavod Miroslav Krleža, Zagreb.

RIHTMAN-AUGUŠTIN, Dunja (1991): Božićni običaji i pučka pobožnost. Etnološka tribina 14:9-15, Zagreb. 
ŠAGI, Bono Zvonimir (1996): Fenomen štovanja sv. Antuna. Zbornik „Kačič “XXVII.-XXVIII, Sveti Antun Padovanski i Hrvati, (1995/1996):113-123, Split.

SCHAUBER, Vera i Michael SCHINDLER (1995): Svetniki in godovni zavetniki. Založba Mladinska knjiga, Ljubljana.

SEKULIĆ, Ante (1986): Narodni život i običaji bačkih Bunjevaca. Zbornik za narodni život i običaje južnih Slavena, sv. 50:303-381, JAZU, Zagreb.

SIJERKOVIĆ, Milan (1996): Pučko vremenoslovlje. Otvoreno sveučilište, Zagreb.

ZEČEVIĆ, Divna (2000): Poželjne biografije. Životopisi svetaca 18. i 19. stoljeća u hrvatskoj književnosti. Durieux, Zagreb.

ZORIĆ, Snježana (1991): Obred i običaj. Zavod za istraživanje folklora, Zagreb. 